\title{
Program Ladit (Lapak Digital) : Optimalisasi Media Digital Sebagai Wadah Dalam Pengembangan Umkm Di Madura
}

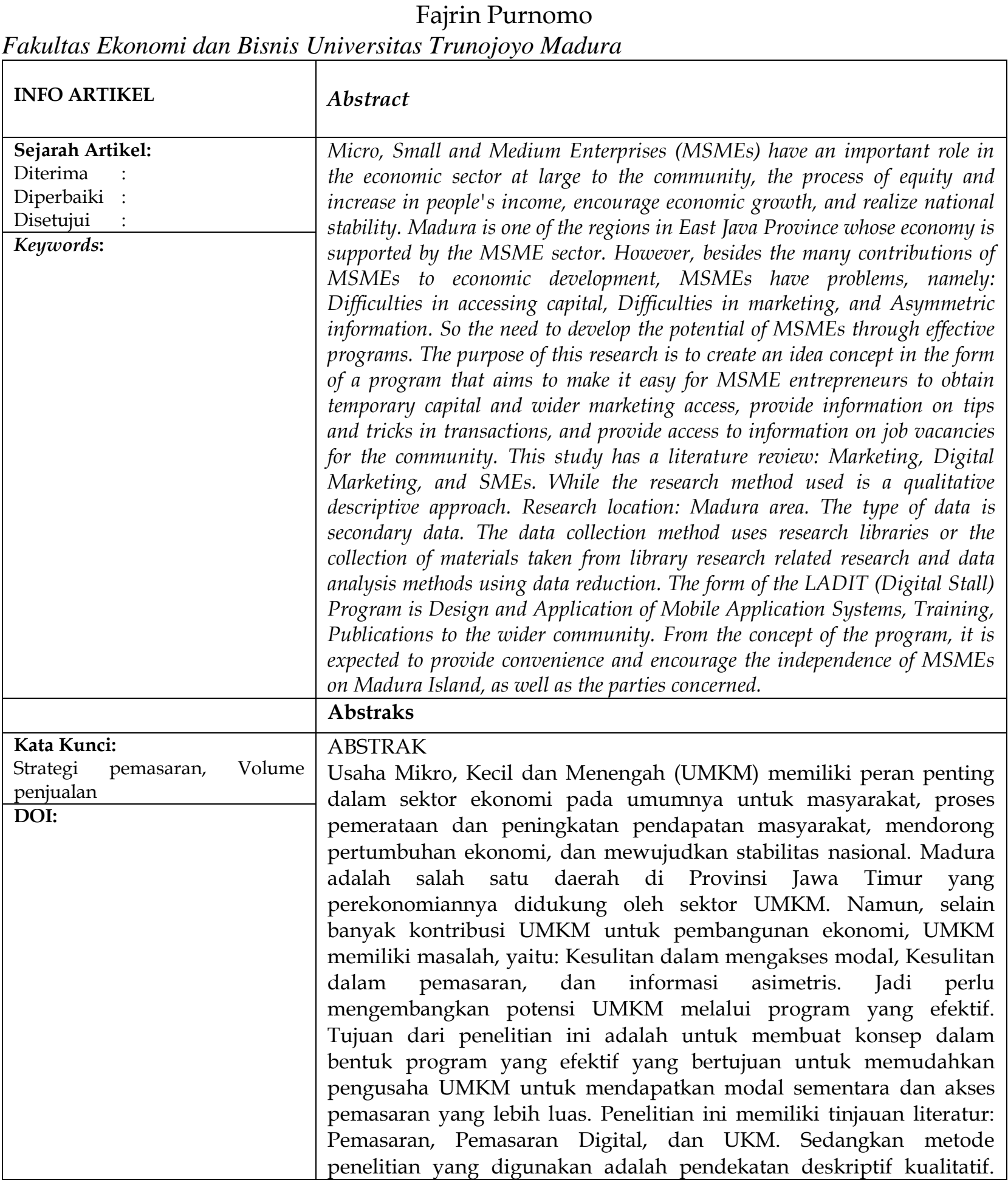




\begin{tabular}{|l|l|l|}
\hline & $\begin{array}{l}\text { Lokasi penelitian: daerah Madura. Jenis data adalah data sekunder. } \\
\text { Metode pengumpulan data menggunakan perpustakaan penelitian } \\
\text { atau kumpulan bahan yang diambil dari perpustakaan penelitian yang } \\
\text { terkait dengan metode penelitian dan analisis data menggunakan } \\
\text { reduksi data. Bentuk Program LADIT (Lapak Digital) adalah aplikasi } \\
\text { LADIT, ladit education center, Pelatihan, dan Pendampingan. Dari } \\
\text { konsep program tersebut, diharapkan dapat memberikan kemudahan } \\
\text { dan mendorong kemandirian UMKM di Pulau Madura, serta pihak- } \\
\text { pihak terkait. }\end{array}$ \\
$\begin{array}{l}\text { Koresponsi: } \\
\text { Emama: Fajrin Purnomo }\end{array}$ & $\begin{array}{l}\text { ISSN: 2355-9643 (Print) } \\
\text { Emsinp7@gmail.com p-ISSN: 2460-3775 (on-line) }\end{array}$ \\
\hline
\end{tabular}

\section{PENDAHULUAN}

Sektor UMKM memiliki peran penting dalam sektor ekonomi secara luas kepada masyarakat, proses peningkatan pendapatan masyarakat, mendorong pertumbuhan ekonomi, serta mewujudkan stabilitas nasional. Berdasarkan data statistik, sektor UMKM menyumbang 99,99\% dari seluruh bisnis yang ada, mempekerjakan 97,16\% angkatan kerja sektor swasta, dan berkontribusi 57,5\% terhadap Produk Domestik Bruto Indonesia (Kementrian Koperasi dan UMKM, 2012). Maka sejalan dengan adanya potensi pada UMKM juga dapat menjawab permasalahan pembangunan perekonomian, sebagaimana kesesuaian dengan tujuan ke-8 yang ada di dalam SDG's yakni mendorong terciptanya pertumbuhan ekonomi yang inklusif dan berkelanjutan, tersedianya lapangan kerja dan pekerjaan yang pantas untuk semua (Wilantara dan Rulli Indrawan, 2016)

Keberadaan UMKM dapat memberikan kontribusi positif terhadap perekonomian juga menjadi upaya solutif dalam pengentasan masalahmasalah ekonomi dan sosial. Madura merupakan salah satu daerah di Provinsi Jawa Timur yang perekonomiannya ditopang oleh sektor UMKM, dengan jumlah UMKM disetiap kabupaten yaitu : UMKM Kabupaten Bangkalan sebanyak 166.768 dengan penyerapan tenaga kerja 210.003, UMKM Kabupaten Sampang sebanyak 195.215 dengan penyerapan tenaga kerja 264.569, UMKM Kabupaten Pamekasan sebanyak 195.554 dengan penyerapan tenaga kerja 257.481, UMKM Kabupaten Sumenep sebanyak 269.005 dengan penyerapan tenaga kerja 486.196 (Dinas Koperasi dan UMKM Jatim, 2016). Namun disisi lain, banyak sekali hambatan yang dilalui dalam menjalankan kegiatan UMKM di Indonesia. Beberapa diantaranya adalah kesulitan permodalan, kesulitan pemasaran, persaingan usaha ketat, kesulitan bahan baku, kurang teknis produksi dan keahlian, keterampilan manajerial kurang, kurang pengetahuan manajemen keuangan, dan iklim usaha yang kondusif (perijinan, aturan/perundangan) dalam yrni (Yuwono, Robby dan R. R. Retno Ardianti, 2013)

Kesulitan akses permodalan menjadi faktor permasalahan utama pada UMKM. Pada umumnya sulitnya akses permodalan disebabkan terlalu sulitnya pengajuan persyaratan secara administratif dan teknis kepada bank. Permasalahan pada faktor yang kedua yaitu sulitnya akses pemasaran yang disebabkan kurangnya pengetahuan sampai dengan adaptasi terhadap internet dan perkembangan teknologi yang dialami pelaku UMKM (Nelsi Islamiyati, 2017). Sehubungan dengan permasalahan tersebut, perlunya pemanfaatan media digital untuk mendorong akses keuangan atau yang dikenal dengan financial technology (Fintech) menjadi upaya solutif untuk mengatasi permasalahan pada UMKM. Fintech mempunyai peran penting dalam membangun akses keuangan yang lebih didalam masyarakat (keuangan inklusif). Adanya tren financial technology ini juga didukung dengan banyaknya pengguna layanan teknologi informasi di Indonesia diantaranya pengguna internet, sosial media, dan mobile phone. Besarnya jumlah pengguna mobile phone yang memiliki akses terhadap internet menjadi salah satu faktor pesatnya pertumbuhan financial technology di Indonesia baik itu di bidang payment, financing, lending dan sebagainya. Berikut ini merupakan jumlah pengguna internet di Indonesia:

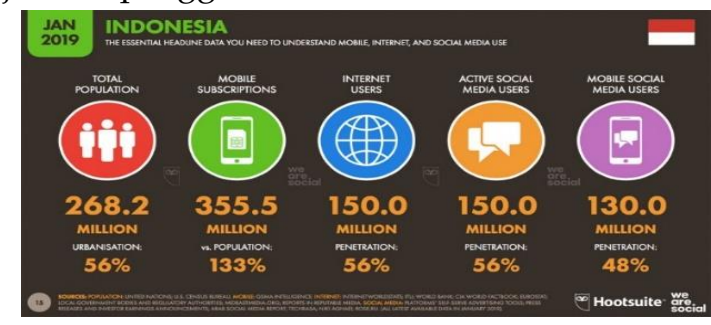


Sumber : Riyanto, Andi Dwi, Hootsuite (We are Social): Indonesian Digital Report 2019, (2019)

Dari data tersebut menunjukkan bahwa pengguna internet pada bulan januari tahun 2019 sebanyak 150.0 juta dengan total populasi 268,2 juta. Sejalan dengan hal tersebut, kemajuan dalam bidang teknologi membuat pengelolaan, penghimpunan dan pendistribusian dana menjadi lebih mudah. Kemajuan di bidang teknologi sekarang ini dapat dimanfaatkan secara menyeluruh untuk kemajuan ekonomi. Merujuk dengan adanya potensi dan kontribusi UMKM terhadap daerah serta beberapa permasalahan yang menyebabkan UMKM tidak bisa berkembang, maka penulis tertarik untuk membuat sebuah gagasan yang solutif guna meningkatkan layanan akses pembiayaan dan pemasaran bagi UMKM di Madura dengan memanfaatkan potensi media digital untuk mengembangkan potensi UMKM di Madura.

\section{TINJAUAN PUSTAKA}

\section{Marketing}

Marketing adalah proses mengidentifikasi dan memenuhi manusia dengan kebutuhan sosialnya. Salah satu definisi tersingkat dari marketing adalah "memenuhi kebutuhan dengan mendapat laba" (Kotler, 2012, p. 27). Definisi marketing oleh The American Marketing Association adalah aktivitas, seperangkat institusi, dan proses menciptakan, mengkomunikasikan, mengirimkan, dan bertukar penawaran yang mempunyai nilai bagi customer, klien, partner, maupun masyarakat pada umumnya (American Marketing Association, 2014).

Dalam Kotler (2012), salah satu konsep penting dalam marketing adalah needs, wants dan demands. Kebutuhan (needs) adalah tuntutan dasar manusia seperti udara makanan, dan pakaian. Kebutuhan ini dapat menjadi keinginan (wants) ketika kebutuhan tersebut diarahkan pada objek yang lebih spesifik lagi, misalnya seseorang yang menginginkan untuk makan nasi goreng dimana sebenarnya kebutuhan dasarnya hanyalah nasi. Sedangkan permintaan (demand) adalah keinginan untuk produk tertentu yang disertai dengan daya beli.

\section{Digital Marketing}

Sawicky(2016) mengartikan digital marketing sebagai eksploitasi terhadap teknologi digital yang digunakan untuk menciptakan suatu saluran untuk mencapai resipien potensial untuk mencapai tujuan perusahaan melalui pemenuhan kebutuhan konsumen yang lebih efektif. Digital marketing didefinisikan juga sebagai kegiatan pemasaran yang menggunakan media berbasis internet (Wardhana, 2015).

Digital Marketing menurut (Prabowo, 2018; Siswanto, 2015) membantu sebuah perusahaan dalam mempromosikan dan memasarkan produk mau- pun jasa yang mereka punya. Digital Marketing juga dapat membuat atau membuka pasar-pasar baru yang sebelunya tertutup karena adanya keterbatasan waktu, cara komunikasi, maupun jarak.

Menurut Strauss dan Frost (2009), tujuh tahap dalam perancangan e-marketing adalah Situation Analysis (Analisis Situasi), E- Marketing Strategic Planning (Strategi Perencanaan E-Marketing), Objectives (Tujuan), E-Marketing Strategy (Strategi E- Marketing), Implementation Plan (Rencana Pelaksanaan), Budget (Anggaran), Evaluation Plan (Rencana Evaluasi). Adapun detil penjelasannya adalah:

a) Situation Analysis (Analisis Situasi)

Tahap pertama merupakan awal dari konsep bisnis dengan melakukan analisis kekuatan, peluang, kelemahan serta ancaman bagi perusahaan. Dalam bagian ini, analisis situasi yang digunakan adalah analisis SWOT. Menurut Rangkuti (2004), analisis SWOT adalah indentifikasi berbagai faktor secara sistematis untuk merumuskan strategi perusahaan. Analisis ini disarankan pada logika yang dapat memaksimalkan Kekuatan (Strengths) dan Peluang (Opportunities), namun secara strategi selalu berkaitan dengan pengembangan misi, tujuan, strategi, dan kebijakan perusahaan. Dengan demikian perencanaan strategi (strategic planner) harus menganalisis faktor-faktor strategi perusahaan (kekuatan, kelemahan, peluang, dan ancaman) dalam kondisi yang ada saat ini. Hal ini disebut Analisis Situasi.

b) E-marketing Strategic Planning (Strategi Perencanaan E-marketing)

Dalam tahap ini terdapat metodologi tujuh langkah sederhana yang membantu dalam mengevaluasidan menganalisis peluang pasar (Market Opportunity Analysis/MOA), yaitu: Mengidentifikasi kebutuhan pelanggan yang belum terpenuhi mengidentifikasi pelanggan tertentu yang akan dituju oleh perusahaan. Menilai keuntungan yang berkaitan dengan kompetisi menilai sumber daya perusahaan untuk memberikan penawaran menilai kesiapan pasar akan teknologi. Menentukan peluang secara konkret. Menilai peluang daya tarik bagi pelanggan. Strategi perencanaan e- marketing meliputi segmentation, targeting, differentiation, 
dan positioning.

c) Objectives (Tujuan)

Tujuan dalam e- marketing mencakup aspek tugas, kuantitas, dan waktu. Tugas (apa yang akan dicapai). Kuantitas yang terukur (seberapa banyak). Time frame (kapan). Sebagian besar emarketing bertujuan untuk mencapai berbagai tujuan seperti berikut: Meningkatkan pangsa pasar. Meningkatkan jumlah komentar pada sebuah blog atau website. Meningkatkan pendapatan penjualan. Mengurangi biaya (misalnya biaya distribusi atau promosi). Mencapai tujuan merek (seperti meningkatkan kesadaran merek). Meningkatkan ukuran database. Mencapai tujuan Customer Relationship Management (CRM) (seperti meningkatkan kepuasan pelanggan, frekuensi pembelian, atau tingkat referensi pelanggan). Memperbaiki manajemen rantai suplai (seperti dengan meningkatkan koordinasi anggota, menambahkan mitra, atau mengoptimalkan tingkat persediaan).

d) E-marketing Strategy (Strategi E- marketing) Strategi e-marketing mencakup strategi mengenai $4 \mathrm{P}$ dan hubungan manajemen (relationship management) untuk mencapai tujuan rencana mengenai Product (Produk), Price (Harga), Place (Saluran Distribusi), dan Promotion (Promosi).

e) Implementation Plan (Rencana Pelaksanaan)

Pada tahap ini perusahaan memutuskan bagaimana untuk mencapai tujuan melalui strategi yang efektif dan kreatif. Pemasar memilih bauran pemasaran $(4 \mathrm{P})$, strategi manajemen dan strategi lain untuk mencapai tujuan rencana dan kemudian menyusun rencana pelaksanaan (Implementation Plan).

f) Budget (anggaran)

Kunci dari perencanaan strategis adalah untuk mengidentifikasi hasil yang diharapkan dari suatu investasi. Selama pelaksanaan rencana, pemasar akan terus memantau pendapatan aktual dan biaya untuk melihat hasil yang telah dicapai. Internet merupakan salah satu tools yang dapat digunakan untuk memantau hasil karena catatan teknologi pengunjung setiap klik. Untuk mendapatkan informasi anggaran yang dapat dipertanggungjawabkan, perlu dibuat perhitungan tentang revenue forecast (perkiraan pendapatan), intangible benefits (manfaat tidak berwujud), cost savings (penghematan biaya), dan e- marketing costs (biaya emarketing).

g) Evaluation Plan (Rencana Evaluasi)

Perencanaan e-marketing dilaksanakan, keberhasilannya tergantung pada evaluasi yang terus-menerus. Jenis evaluasi ini tergantung pada tujuan rencana. Untuk menentukan hasil pemasarannya, perusahaan dapat menggunakan balanced scorecard untuk mengukur kesuksesan dari program internet marketing dan apakah program internet marketing tersebut cocok sesuai dengan objektif dari perusahaan.

Usaha Mikro Kecil Menengah (UMKM)

Pada Bab I pasal 1 UU No 20 Tahun 2008 tentang Usaha Mikro, Kecil, dan Menengah (UMKM), maka yang dimaksud dengan Usaha Mikro, Kecil, dan Menengah adalah:

1) Usaha Mikro adalah usaha produktif milik orang perorangan dan/atau badan usaha perorangan yang memenuhi kriteria Usaha Mikro sebagaimana diatur dalam Undang-Undang ini.

2) Usaha Kecil adalah usaha ekonomi produktif yang berdiri sendiri, yang dilakukan oleh orang perorangan atau badan usaha yang bukan merupakan anak perusahaan atau bukan cabang perusahaan yang dimiliki, dikuasai, atau menjadi bagian baik langsung maupun tidak langsung dari Usaha Menengah atau Usaha Besar yang memenuhi kriteria Usaha Kecil se-bagaimana dimaksud dalam Undang-Undang ini.

3) Usaha Menengah adalah usaha ekonomi produktif yang berdiri sendiri, yang dilakukan oleh orang perorangan atau badan usaha yang bukan merupakan anak perusahaan atau cabang perusahaan yang dimiliki, dikuasai, atau menjadi bagian baik langsung maupun tidak langsung dengan Usaha Kecil atau Usaha Besar dengan jumlah kekayaan bersih atau hasil penjualan tahunan sebagaimana diatur dalam UndangUndang ini.

Berdasarkan definisi di atas maka pada intinya Usaha Mikro, Kecil, dan Menengah adalah suatu bentuk usaha ekonomi produktif yang dilakukan oleh orang perseorangan atau badan usaha perorangan yang memenuhi kriteria Usaha Mikro, Kecil, dan Menengah.

\section{METODOLOGI}

Jenis Penulisan

Adapun Metode penulisan yang digunakan oleh penulis adalah dengan menggunakan metode studi literatur atau kualitatif. Data diperoleh melalui literatur terkait UMKM. Pengambilan kesimpulan dilakukan dengan cara menggabungkan antara penelitian terdahulu, data yang tersedia dan beberapa studi literatur. Data yang digunakan adalah data sekunder yang berasal dari tinjauan literatur dan website yang terkait.

Data dikumpulkan melalui metode Studi Pustaka, 
yaitu dengan cara mempelajari literatur-literatur yang terkait dengan penelitian. Penulisan penelitian ini menggunakan teknik analisis data deskriptif kualitatif. Data-data yang diperoleh dari tinjauan literatur maupun website terkait disusun menjadi sebuah fakta-fakta yang aktual untuk kemudian dilakukan pembahasan solusi. Melalui hal tersebut, diharapkan tujuan dari pembuatan konsep Program LADIT tersebut dapat berdampak positif terhadap perekonomian masyarakat.

\section{HASIL PENELITIAN DAN PEMBAHASAN}

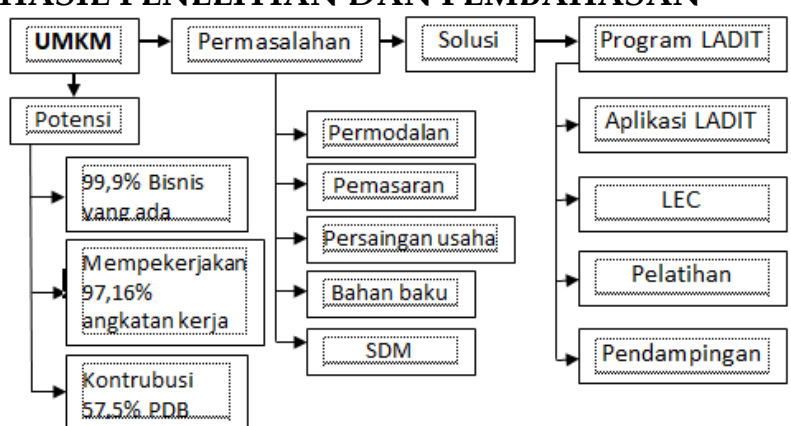

Program LADIT (Lapak Digital) merupakan sebuah wadah yang dapat menaungi berbagai UMKM yang ada di Madura, disini yang dijadikan studi kasus yaitu Kabupaten Sumenep, Kabupaten Pamekasan, Kabupaten Sampang, dan Kabupaten Bangkalan. Kemudian aplikasi yang nantinya dapat digunakan bernama LADIT, LADIT merupakan sebuah gagasan Fintech yang tujuannya untuk menjembatani masyarakat baik para pembeli produk UMKM maupun para investor yang ingin menginvestasikan dananya pada sektor UMKM dan para penerima manfaat dana yakni pelaku UMKM. Alasan penulis menggunakan Fintech dalam konsep program LADIT agar pembangunan perekonomian terkhusus pada sektor UMKM semakin optimal dan berkelanjutan serta sejalan dengan era ekonomi digital pada masa sekarang ini.

Program utama dari LADIT adalah adanya aplikasi yang bertujuan untuk mempertemukan pelaku UMKM dengan mitra dan masyarakat yang bertindak sebagai investor atau pembeli. Sebagai langkah awal yang harus dilakukan dalam memperkenalkan aplikasi LADIT yakni dengan memberikan sosialisasi kepada pelaku UMKM di Madura. Sedangkan dalam melakukan promosi, aplikasi LADIT menggunakan media online dan juga menggunakan media offline melalui brosur yang di cetak lalu diberikan di jalur akses memasuki kawasan Madura, yakni melalui jembatan Suramadu serta pelabuhan Kamal. Media ini cukup efektif jika direalisasikan karena akses masuk wilayah Madura bermula dari 2 lokasi tersebut.

Aplikasi LADIT memiliki beberapa fitur dan tampilan yang menarik, diantaranya adalah: (1) Halaman beranda: halaman utama yang menampilkan menu mengenai UMKM yang berada di empat kabupaten di Madura (Sumenep, Pamekasan, Sampang, dan Bangkalan), dan juga beberapa fitur diantaranya yaitu : Pasar Online berisi tentang informasi mengenai berbagai produk UMKM Madura, Produk Unggulan berisi tentang informasi mengenai produk unggulan yang kreatif dan inovatif yang ada di Madura, Mitra Usaha berisi informasi mengenai jasa angkutan yang bertindak sebagai penyalur barang dari produsen ke konsumen dan toko penitipan penjualan barang. Lowongan Kerja berisi informasi mengenai lapangan pekerjaan pada UMKM yang tujuannya agar mempermudah masyarakat madura dalam mencari pekerjaan pada daerah sendiri tanpa harus pergi ke daerah lain, Hot Info berisi informasi terbaru yang berkaitan dengan adanya informasi diskon maupun adanya informasi penurunan harga produk, pada menu Berbagi inspirasi ini sebagai sarana berbagi motivasi dalam bentuk artikel dan gambar. (2) Halaman UMKM Kabupaten: berisi informasi tentang UMKM yang ada di Kabupaten yang di pilih. Informasi tersebut diantaranya berupa: Nama usaha, Nama Produk, Alamat, No. HP dan Foto Produk. Pada halaman ini, penggguna yang tertarik terhadap produk atau usaha dapat melakukan cek informasi lebih detail dengan meng-klik menu "Detail". (3) Halaman Detail: memuat informasi lengkap tentang usaha. Pada halaman ini, pengguna yang memiliki saldo dapat melakukan pembelian produk dengan mengklik "BELI PRODUK" atau melakukan pemberian investasi pada UMKM dengan meng-klik "INVESTASI". Menu "INVESTASI" akan menampilkan jumlah dana yang sudah terhimpun dan intruksi untuk memasukkan nominal investasi serta presentase bagi hasil yang diinginkan oleh investor sedangkan menu "BELI PRODUK" pengguna akan diminta untuk mengisi jumlah produk yang akan dibeli, alamat tujuan pengiriman, dan No. HP penerima produk. Rancangan Prototype Aplikasi LADIT: 


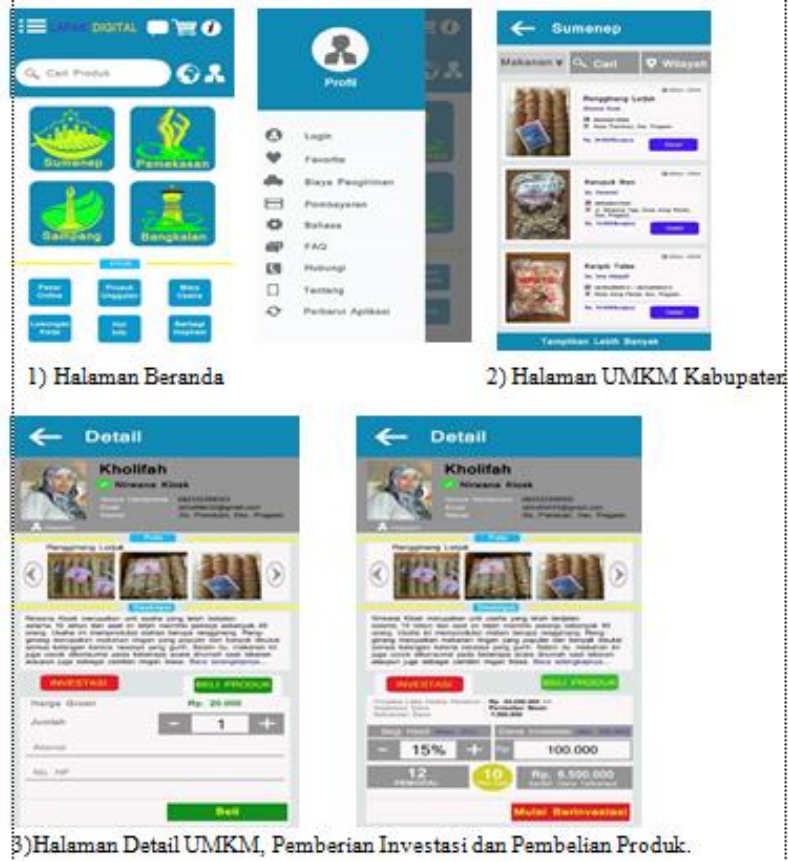

3)Halaman Detail UMKM, Pemberian Investasi dan Pembelian Produk.

Program LADIT yang selanjutnya yaitu LEC (LADIT Education Center). LEC merupakan wadah/tempat bagi para UMKM Madura untuk mencari, berbagi informasi dan mengajukan keluhan serta permasalahan pelaku usaha. LEC memberikan manfaat bagi UMKM yang terintegrasi dengan membentuk rumah layanan untuk UMKM. Maka LEC memberikan layanan rutin berupa konsultasi, pelatihan dan pemberdayaan untuk meningkatkan kemampuan dan keterampilan para pelaku usaha. Bentuk dari pelatihan meliputi pelatihan keterampilan usaha produk inovatif, manajemen pemasaran, manajemen keuangan, penyusunan study kelayakan usaha, man ajemen eksport. Pihak yang terlibat dalam memberikan pelatihan antara lain akademisi, dan pemerintah target dari pelatihan ini yaitu para pelaku usaha dan calon pelaku usaha sehingga harapannya dengan adanya pelatihan ini dapat meningkatkan kualitas SDM para pelaku usaha dan menumbuhkan minat wirausaha baru pada kalangan pemuda yang pada akhirnya dapat mengurangi jumlah pengangguran di Madura dan UMKM bisa bersaing secara global. Selain pelatihan juga adanya upaya untuk pendampingan UMKM yang dilakukan melalui pembinaan secara intensif dan terstruktur. Pihak LADIT akan melakukan pendampingan kepada UMKM yang menerima modal pembiayaan. Pihak LADIT akan bekerjasama dengan akademisi dan pemerintah untuk melakukan pendampingan secara berkala mengenai pengelolaan usaha yang terkait dengan keterampilan operasional maupun manajerial. Tujuan dari adanya pemberdayaan ini, untuk memantau perkembangan usaha dan memastikan usaha berjalan dengan baik, yang selanjutnya informasi tersebut dapat diberikan kepada investor melalui aplikasi LADIT.

Dengan konsep ini diharapkan UMKM dapat berkembang secara pesat dengan hal tersebut inovasi dari UMKM dapat memberikan pendapatan lebih terhadap UMKM itu sendiri dan masyarakat disekitarnya. Program ini melibatkan berbagai pihak. Pihak-pihak yang terkait dalam program ini seperti akademisi, pemerintah, pelaku UMKM, dan mitra UMKM. Ketika posisi UMKM menjadi sentral bersamaan dengan adanya mitra UMKM, kemudian didukung oleh peraturan dari pemerintah, dan juga didampingi oleh akademisi maka akan membentuk sebuah konsep yang baik. Sehingga dampaknya terhadap perekonomian di Madura juga baik. Selain itu dengan adanya program ini mampu memberikan akses yang lebih baik kepada pihak luar untuk mengetahui potensi UMKM yang ada di Madura yang memiliki berbagai produk yang inovatif dan kreatif sehingga mereka dapat berinvestasi atau membeli produk tersebut khususnya masyarakat yang berada di luar Madura.

\section{DAFTAR PUSTAKA}

Anggraeni Dwi Feni,Hardjanto Imam \& Hayat Ainul. 2013. Pengembangan Usaha Mikro, Kecil, Dan Menengah (Umkm)Melalui Fasilitasi Pihak Eksternal Dan Potensi Internal (Studi Kasus Pada Kelompok Usaha "Emping Jagung" Di Kelurahan Pandanwangi Kecamatan Blimbing, Kota Malang). Jurnal Administrasi Publik.Vol.1 No.6. hlm 1287.

Hendrawan, Andi, dkk. 2019. Pengaruh Marketing Digital Terhadap Kinerja Penjualan Produk Umkm Asti Gauri Di Kecamatan Bantarsari Cilacap.

Jurnal Administrasi dan Kesekretarisan.Vol.4 No.1. hlm 52-54

Nelsi Islamiyati. 2017. 5 Permasalahan Utama yang Dihadapi Para Pelaku UMKM. https://www.jagoanhosting.com/blog/5permasalahan-utama-yang-dihadapi-parapelaku-umkm/. Diakses pada tanggal 27 November 2018 pukul 19.34.

Riyanto, Andi Dwi. 2019. Hootsuite (We are Social): Indonesian Digital Report 2019. https://andi.link/hootsuite-we-are-socialindonesian-digital-report-2019/. Diakses 
pada tanggal 5 November 2019 pukul 14.38.

Rosalina, Sherly, Subagio Hartono.2016. Analisa Pengaruh Product Image Terhadap Purchase Intention Dengan Trust Sebagai Variabel Intevening Pada Blesscon Pt. Superior Prima Sukses. Korespondensi penulis.Vol.1 No.1. hlm 3

Supratman, Lucy Pujasari. 2018. Pengguna Media Sosial oleh Digital Native. Jurnal Ilmu Komunikasi. 15 (1): 48.

Wilantara, Rio F dan Rulli Indrawan. 2016. Strategi dan Kebijakan Pengembangan UMKM. https://rullyindrawanblog.files.wordpress.c om/2017/12/editor-strategi-dan-kebijakanpengembangan-umkm.pdf. Diakses pada tanggal 24 November 2018 pukul 19.18.

Yuwono, Robby dan R. R. Retno Ardianti. 2013. Analisa Faktor-faktor Penghambat Pertumbuhan USAha Mikro dan Kecil pada Sektor Formal di Jawa Timur. Jurnal Agora. Vo. 1 No. 3. Hlm. 2. 